\title{
Proceeding
}

Supplementary Issue: Spring Conferences of Sports Science. Costa Blanca Sports Science Events, 19-20 June 2020. Alicante, Spain.

\section{Posture and skeletal muscle disorders of the neck due to the use of smartphones}

\author{
SARA ALIBERTI ${ }^{1}$, PIERO LUIGI INVERNIZZI², RAFFAELE SCURATI², TIZIANA D'ISANTO1 \\ 1 University of Salerno, Italy \\ 2University of Milan, Italy
}

\begin{abstract}
The aim of the research is to verify some variables on the use of the smartphone, associated with musculoskeletal pain and any other data that amplify its dependence or use. Smartphones have become an integral part of many people's lives. Most of the kids spend their days sharing photos, stories, videos about their daily lives such as lunches, trainings, travels, shopping. In short, there is an endless list of reasons to be mentally and physically connected to smartphones. However, how much does the excessive use of smartphones affect your body? The widespread abuse of mobile technology can be translated into a physical condition harmful to the human body, known as "Text Neck". Incorrect posture due to incorrect use of the smartphone, flexing the head to send messages and excessive time spent in this position, over time can lead to the presence of musculoskeletal pain in the neck region. A questionnaire of 14 questions, prepared with Google Modules and disseminated through sharing on social networks and it, was submitted to 334 university students of different gender and age. Descriptive statistics was conducted to evaluate the responses obtained from the subjects. The percentage of responses for each question was calculated.
\end{abstract}

Keywords: Text neck; Pain; Physical activity; Wellness; Cervical spine.

\section{Cite this article as:}

Aliberti, S., Invernizzi, P.L., Scurati, R., \& D'Isanto, T. (2020). Posture and skeletal muscle disorders of the neck due to the use of smartphones. Journal of Human Sport and Exercise, 15(3proc), S586-S598. doi:https://doi.org/10.14198/ihse.2020.15.Proc3.11

Corresponding author. University of Salerno, Italy.

E-mail: s.aliberti17@studenti.it

Supplementary Issue: Spring Conferences of Sports Science. Costa Blanca Sports Science Events, 19-20 June 2020. Alicante, Spain.

JOURNAL OF HUMAN SPORT \& EXERCISE ISSN 1988-5202

(c) Faculty of Education. University of Alicante

doi:10.14198/jhse.2020.15.Proc3.11 


\section{INTRODUCTION}

By posture, we mean the position of the human body in space and the relationship between the body segments and the surrounding environment (Raiola, 2017, Raiola, di Tore, 2017, Raiola, 2014, 2013, Altavilla, 2014, Gaetano, 2012, Viscione et al, 2019). Many authors talk about the concept of "ideal posture" (D'Isanto, 2019, D'Isanto et al., 2019), which includes keeping the body in balance in the cheapest possible way (D'Elia, 2019, Russo et al, 2019ab) during the various gestures we make. However, in everyday life, most of the industrialized population adopts incorrect postures, which in the end cause pain and related disease for the lifelong wide and so on (Sgrò et al, 2018, 2017ab, 2016, 2015, 2009). One of the most used postures is the Forward Head Posture (FHP) sometimes called "Scholar's Neck", "Text Neck" or "iHunch", which refers to a posture in which the head is positioned in front of the body. This means that the skull flexes forward, more than an inch above the atlas. FHP involves a greater flexion of the lower cervical vertebrae and upper thoracic regions, an increase in the extensions of the upper cervical vertebrae and the extension of the occiput on C1. It can cause headache, pain (Di Domenico et al., 2019) in the neck and shoulders, together with a reduction in cervical movement and muscle stiffness. People of all ages spend hours and hours a day bent over different types of handheld devices, neglecting their posture while absorbed in writing text messages or surfing the net. This repetitive stance is almost constant and there is not the adequate physical and sport activities (Invernizzi et al, 2020, 2014ab, 2008). In some cases the competitive sport activities is very important for whole exercise conditions and stress and helps (Izzo et al, 2020ab, Izzo et al, 2019abc), despite the excessive stress could be important negative factors and needs to help the physical performance for lower limb and knee (Sannicandro et al, 2017, 2016, 2015ab, 2014, 2012ab, 2011ab, 20210, 2008). When we bring our eyes close to the screen, we bring the head forward, stressing the neck muscles, curving the shoulders forward, closing the chest muscles, which in the end cause pain and discomfort. The neck curves by 45 degrees giving a pressure of over $23 \mathrm{~kg}$, triggering a compensating reaction that advances the pelvis and flattens the cervical and lumbar curves accentuating the dorsal one (Figure 1).

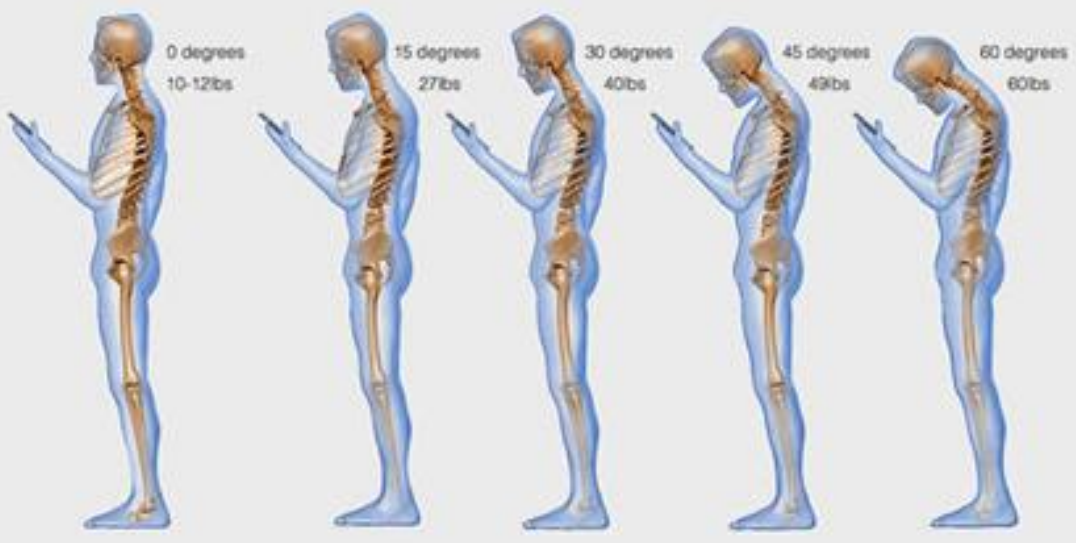

Figure 1. The weight seen by the spine increases when flexing the neck at varying degrees. An adult head weighs 10-12 pounds in the neutral position. As the head, tilts forward the forces seen by the neck surges to 27 pounds at 15 degrees, 40 pounds at 30 degrees, 49 pounds at 45 degrees and 60 pounds at 60 degrees (Hansraj, 2014). 
The loss of the natural curvature of the cervical brings an increase in tension on the neck and shoulders and this weight over time results in pain, stiffness and back pain. The widespread abuse of mobile technology can be translated into a physical condition harmful to the human body, known as "Text Neck". Today is consolidated the importance of physical activity to health (D'Isanto, 2016, Ferrara et al, 2019, Raiola, 2015, Severino et al, 2019), it can adversely affect both the mental and physical health (Altavilla, 2016), and so it is important to know the effects of exercise for the treatment of widespread diseases (Tiziana et al., 2017). Purpose of the research is to verify some variables on the use of the smartphone, associated with musculoskeletal pain and any other data that amplify its dependence or use.

\section{METHOD}

The method of the study is qualitative/quantitative, administering through a special online platform a questionnaire of 14 questions, prepared with Google Modules and disseminated through sharing on social networks. The questionnaire was submitted to university students of different gender and age (D'Elia et al., 2018). The sample has an age includes between eighteen and twenty-six years, of which most have nineteen years $(27,2 \%)$. The questionnaire was composed of:

- Demographic data relating to gender, age, habits that affect health, such as exercise;

- Data on the use of the smartphone, relating to time, the reason for using the device;

- Data on the level of dependence on the smartphone, through three statements, which, if positive, indicate an addiction.

- Data on posture and any disturbances.

\section{Data analysis}

Descriptive statistics was conducted to evaluate the responses obtained from the subjects. The percentage of responses for each question was calculated.

\section{RESULTS}

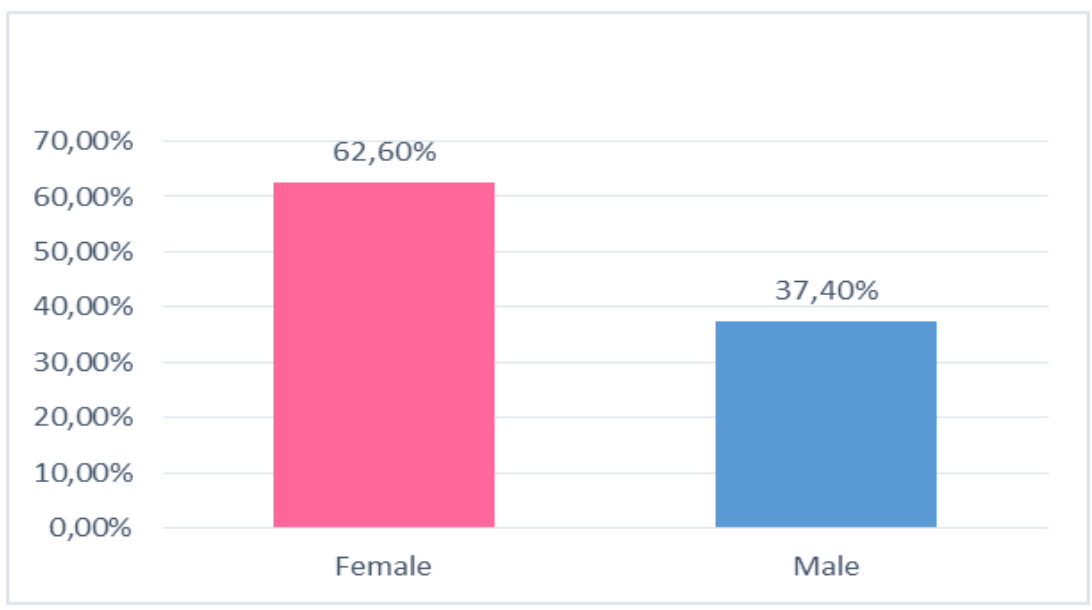

Figure 2. Belonging to gender (male or female).

This graph shows us the percentage of participation between females and males (female $62.6 \%$ and male $37.4 \%)$. 


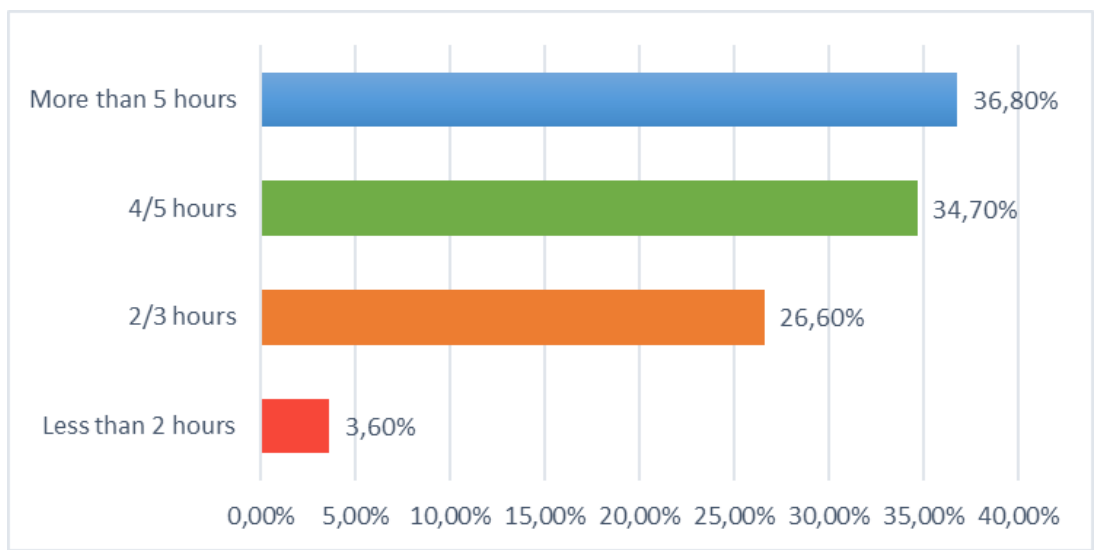

Figure 3. Smartphone usage time.

This graph shows that a high percentage of students (36.8\%) use their mobile phone for more than 5 hours, $34.7 \%$ use it for $4 / 5$ hours, $24.6 \%$ for $2 / 3$ hours, while only $3.6 \%$ use it for less than two hours.

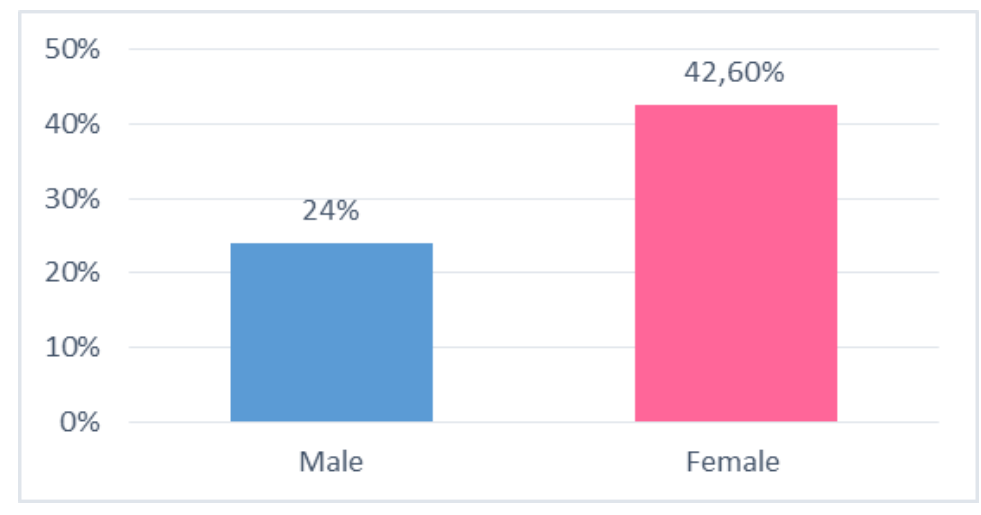

Figure 4. Smartphone usage time for more than 5 hours in males and females.

This graph shows us that $42.6 \%$ of women use the smartphone daily for more than 5 hours compared to $24.0 \%$ of men.

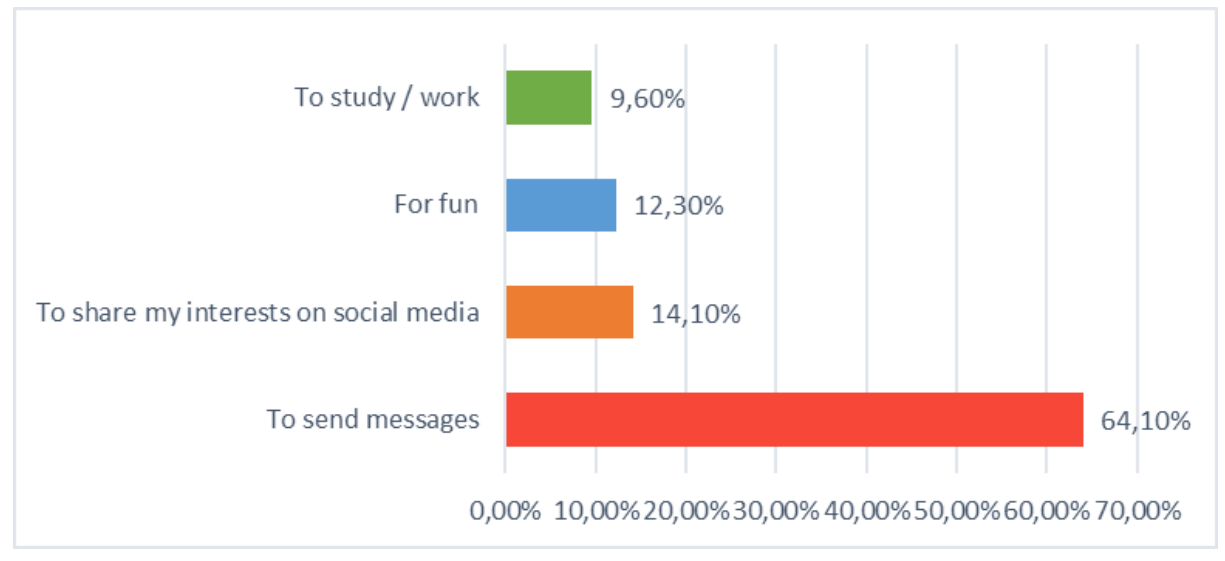

Figure 5. Main reasons smartphone use. 
This graph shows us that the main reason why students use mobile phones (Fig. 5) is to send messages $(64.1 \%)$, followed by sharing their interests on social media, such as Instagram and Facebook (14.1\%), for fun $(12.3 \%)$, for study and work $(9.6 \%)$.

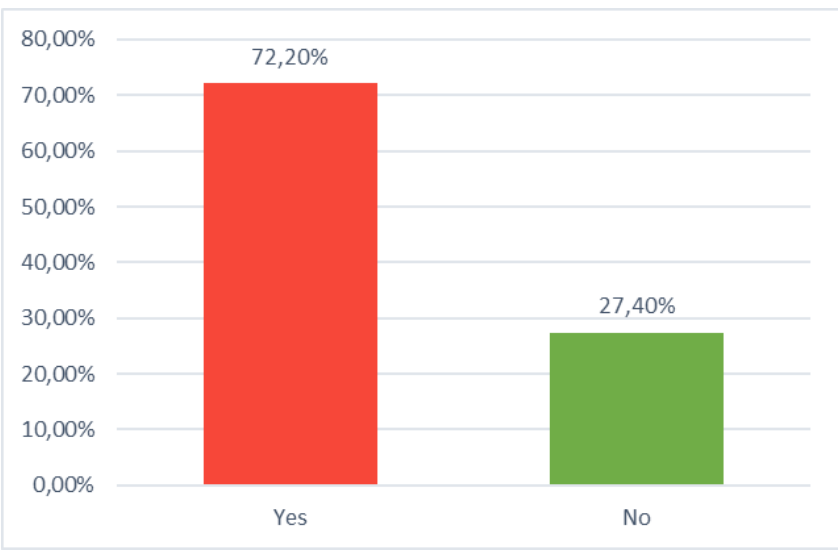

Figure 6. Do you often check the screen to check for new notifications?

This graph shows us that around $72.2 \%$ often check their mobile phones to check for notifications.

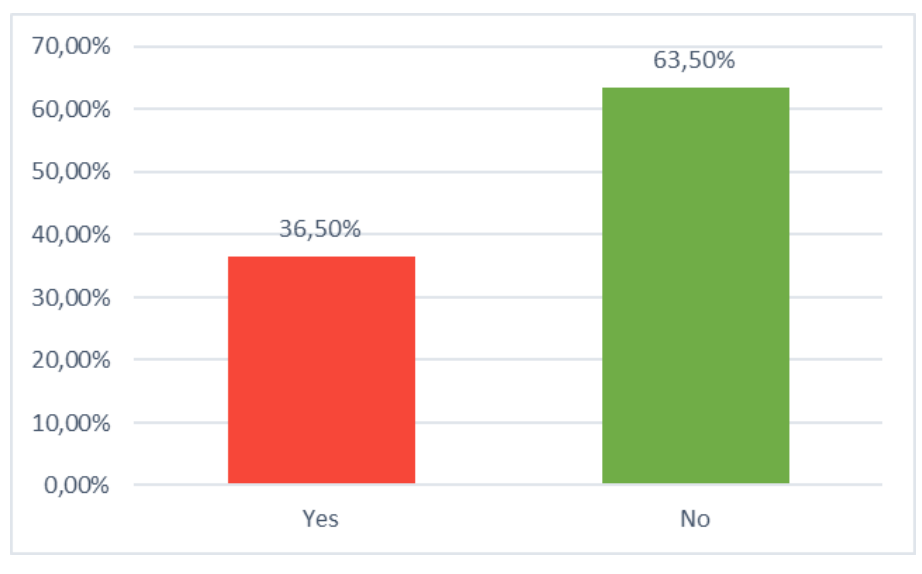

Figure 7. Do you panic when your phone has a low battery and can't charge it right away?

This graph shows us that about $63.5 \%$ do not panic when the mobile phone has a low battery and cannot recharge it immediately. 


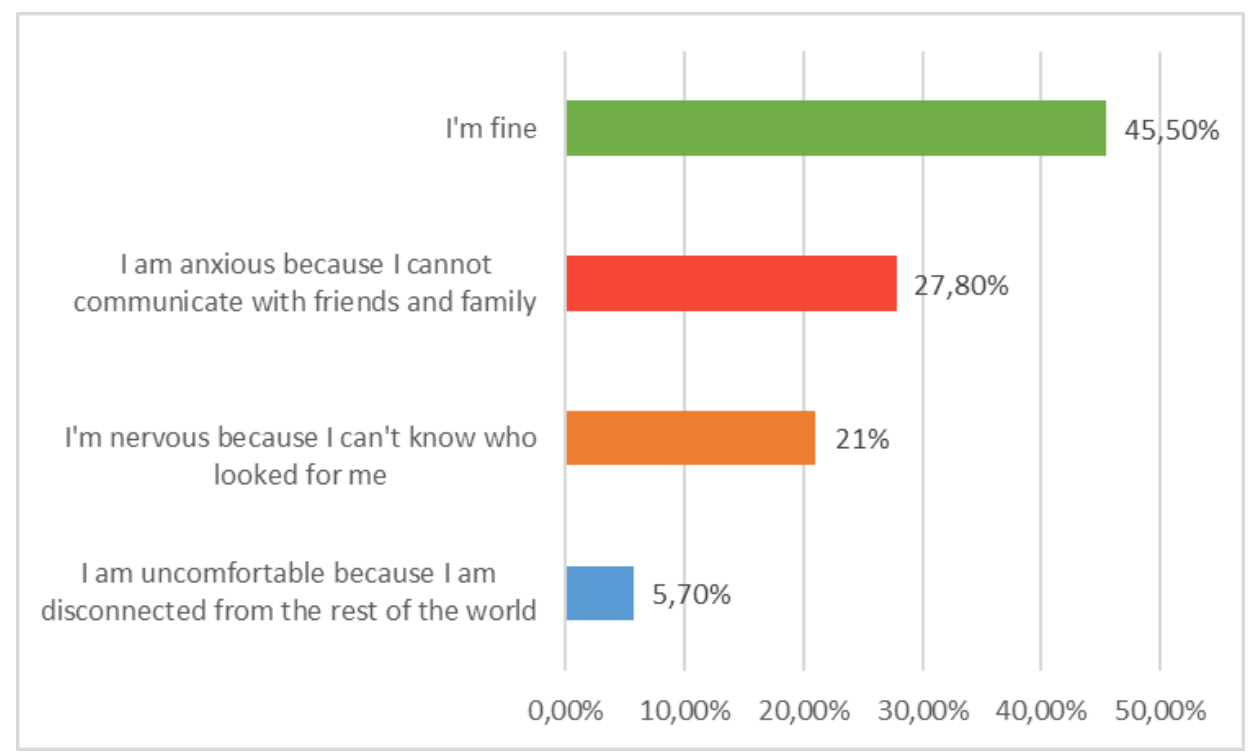

Figure 8. If I don't have my smartphone with me.

This graph shows us that around $45.5 \%$ of students are doing well without a cell phone. However, $27.8 \%$ responded that they feel anxious, because they cannot communicate with family and friends, $21 \%$ are nervous because they cannot know if they have been searched and $5.7 \%$ feel uncomfortable because they are not disconnected from the rest of the world, and cannot control the arrival of notifications from social media.

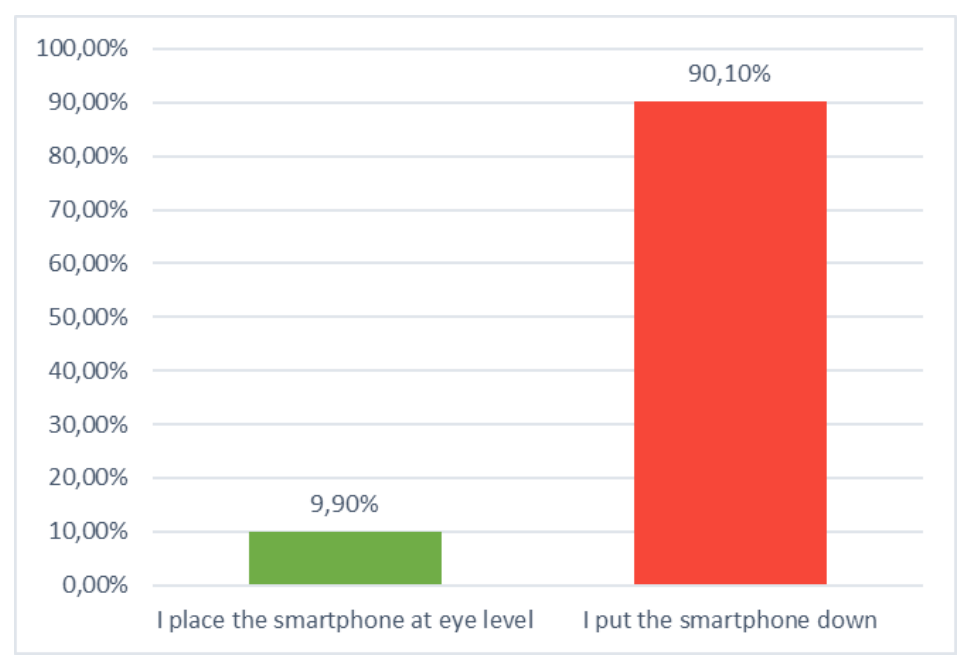

Figure 9. Your posture while using your smartphone.

This graph shows us that almost the total of students (90.1\%) adopt an incorrect posture when using the smartphone. 


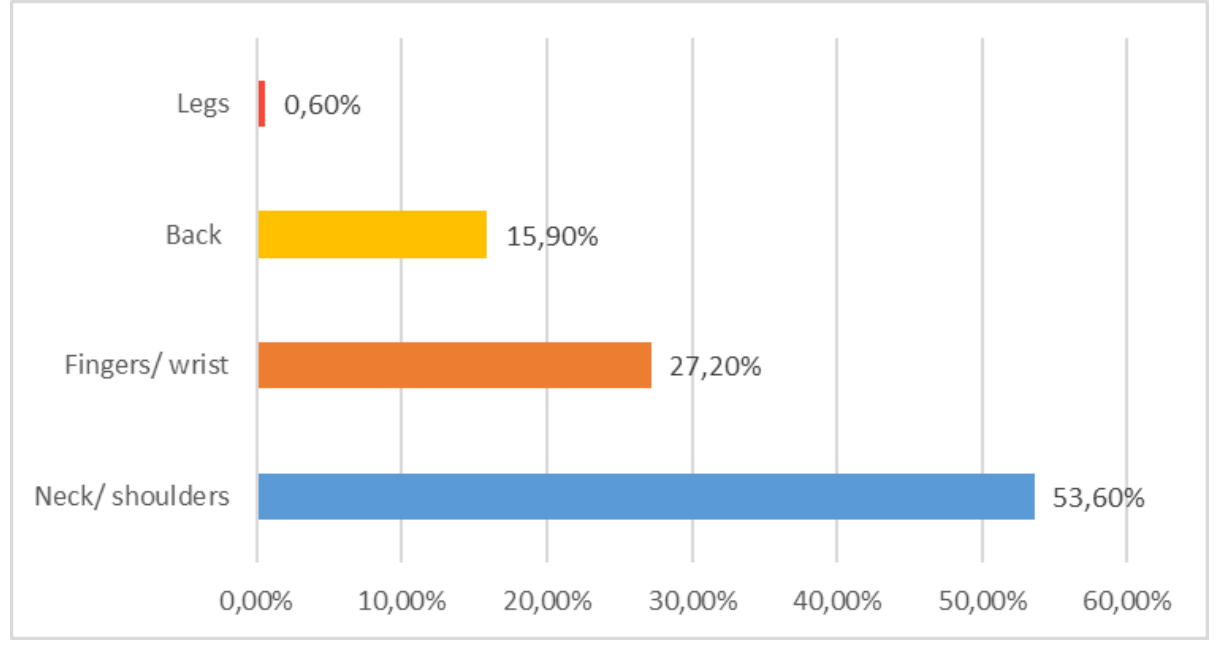

Figure 10. In which part of the body do you feel pain/discomfort after prolonged use of the smartphone?

This graph shows us that the prevalence of skeletal muscle disorders is higher in the neck / shoulders $(56.3 \%)$, and fingers / wrist $(27.2 \%)$, less prevalent in the back (15.9\%) and legs $(0.6 \%)$.

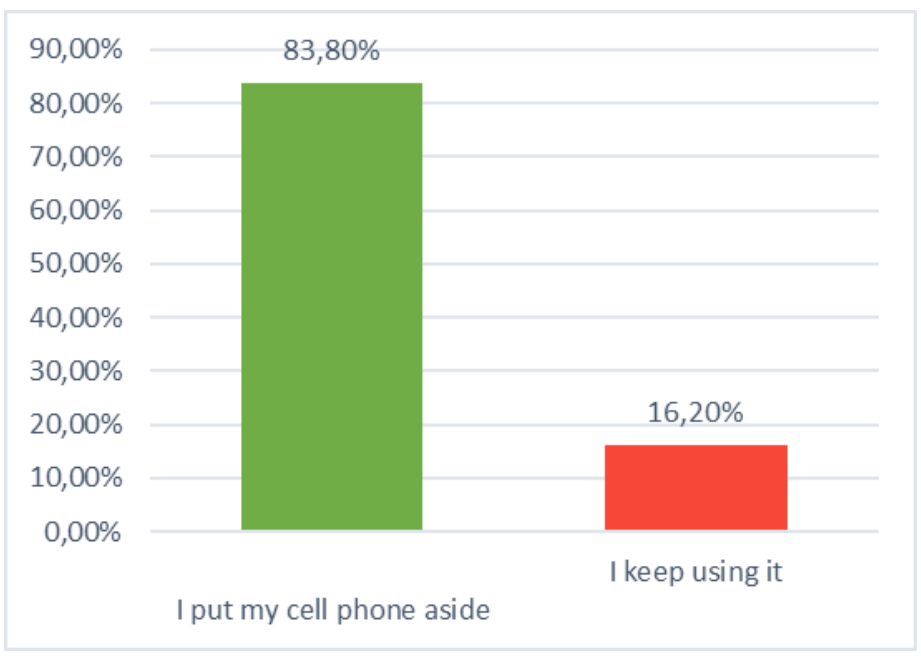

Figure 11. When you feel pain/discomfort, what do you do?

This graph shows us that a very high percentage $(83.8 \%)$, when perceiving pain or discomfort, puts aside the mobile phone, while $16.2 \%$ continues to use it. 


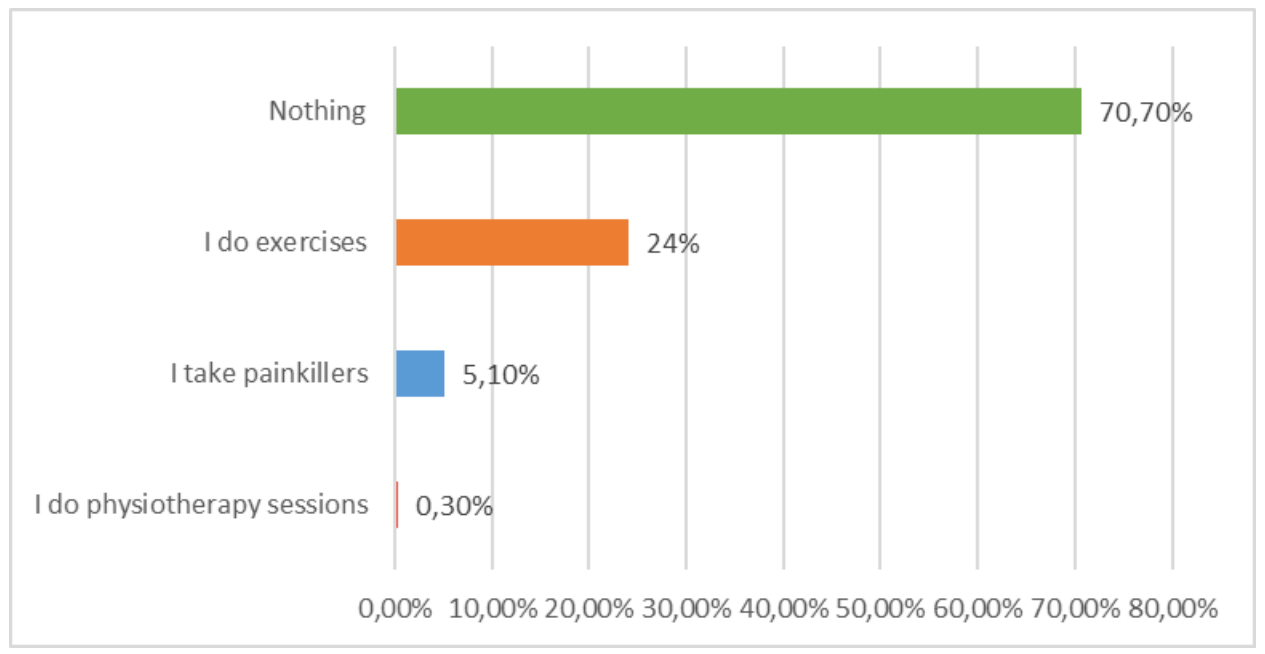

Figure 12. What do you do to reduce or prevent pain?

This graph shows us that to reduce pain, the majority (70.7\%) do nothing, $24.0 \%$ perform exercises, $5.1 \%$ take painkillers and $0.3 \%$ do physiotherapy sessions.

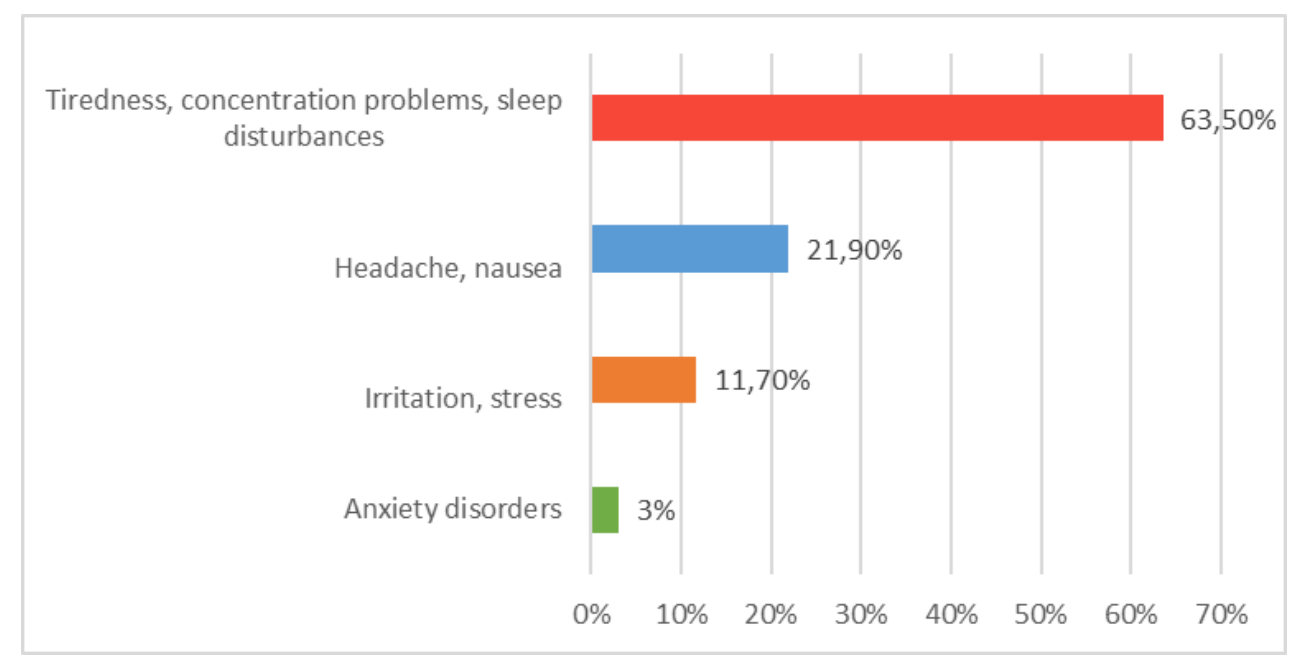

Figure 13. On a psychic level, what problem is caused by prolonged use of your smartphone?

This graph shows us that on a psychic level, most of the samples (63.5\%) show the classic symptoms of prolonged use of the smartphone, therefore feeling tired and concentration problems, sleep disturbances, $21.9 \%$ head and nausea, $11.7 \%$ irritation and stress, $3.0 \%$ anxiety disorders. 


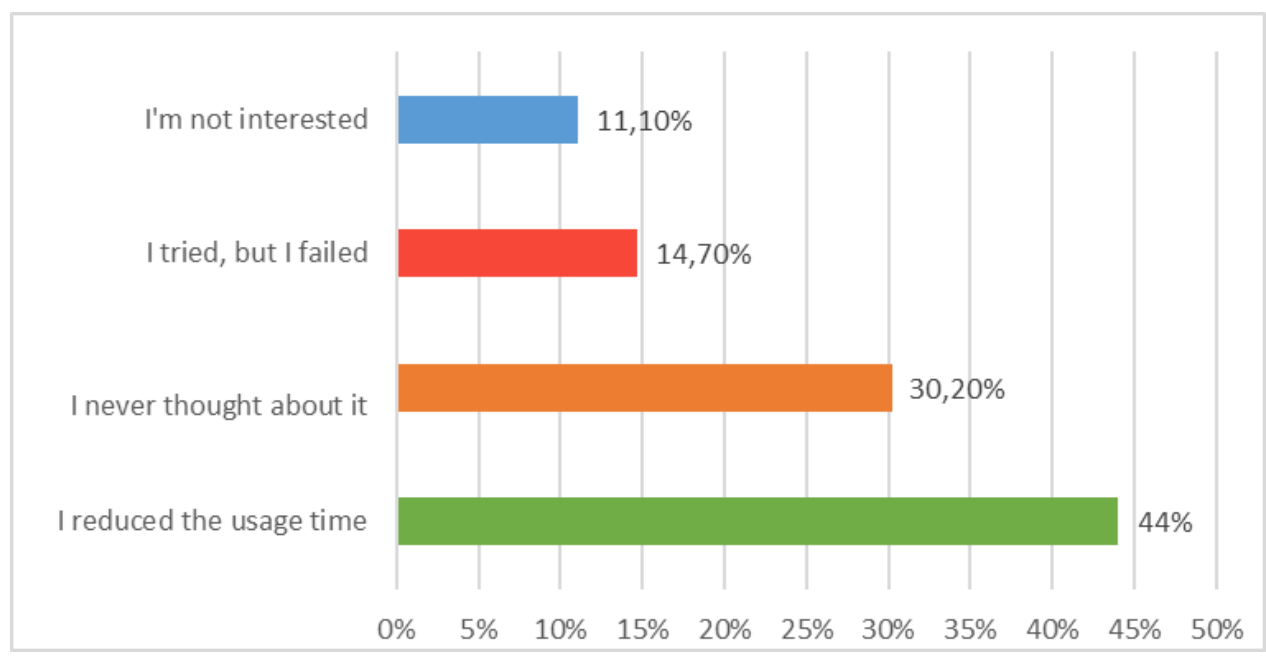

Figure 14. Have you ever tried to reduce your smartphone usage time?

This graph shows us that $44.0 \%$ of students have reduced their smartphone usage time, $30.2 \%$ have never thought about it, $14.7 \%$ have tried, but failed, while at $11,1 \%$ do not care.

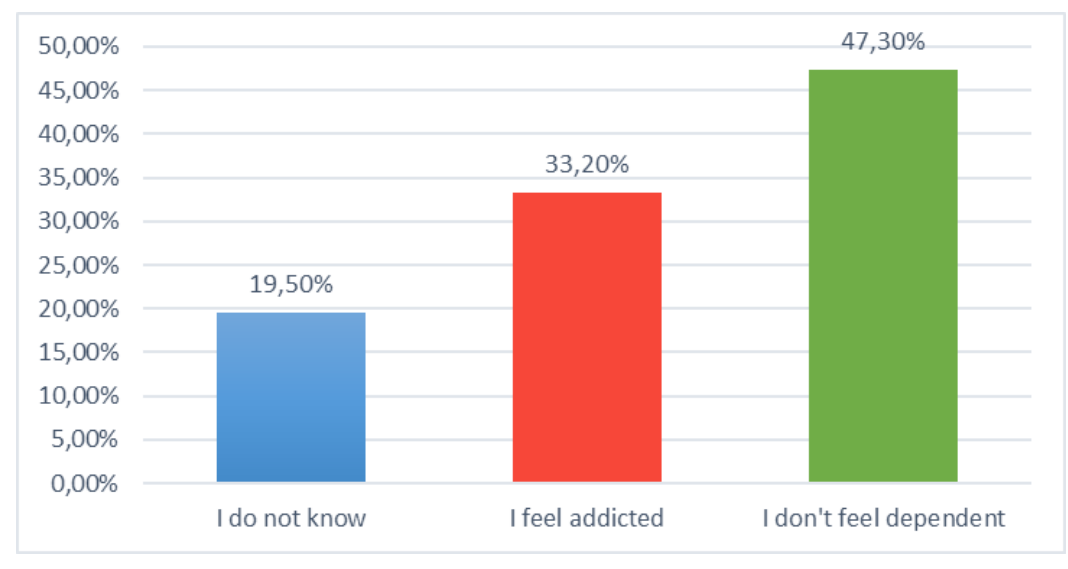

Figure 15. Self-assessment of smartphone addiction.

This graph shows us that the majority (47.3\%) do not feel dependent, $33.2 \%$ feel dependent, $19.5 \%$ do not know.

\section{DISCUSSION}

The percentage of participation between females and males is shown in Figure 2 . As for the daily smartphone usage time, a high percentage of students (36.8\%) use the mobile phone for more than 5 hours, $34.7 \%$ use it for $4 / 5$ hours, $24.6 \%$ for $2 / 3$ hours, while only $3.6 \%$ use it for less than two hours. (Figure 3 ) However, it is women who use it for longer, than men, as we see in the graphs: $42.6 \%$ of women use the smartphone daily for more than 5 hours against $24.0 \%$ of men (Figure 4 ). The main reason they use mobile phones (Figure 5 ) is to send messages $(64.1 \%)$. Some studies claim that text messaging involves more head flexes than surfing the Internet or watching videos. About $72.2 \%$ check their cell phones often to check for notifications (Figure 6). The insistent need to check the mobile phone at various times of the day refers to the idea of addiction. 
Do you panic when your phone has a low battery and cannot recharge right away? To this question $63.5 \%$ replied that they did not panic, which is a positive factor, since it means that the discharged cell phone does not affect the psychological state of the subjects (Figure 7). To the question, "If I don't have my smartphone with me ...?" about $45.5 \%$ said they are doing well, and they can do without it, and so far, it seems to be positive. However, $27.8 \%$ he replied that he is anxious because he cannot communicate with family and friends, $21 \%$ are nervous because he cannot find out if he has been searched and $5.7 \%$ feel uncomfortable because he is not disconnected from the rest of the world and cannot control the arrival of notifications from social media (Figure 8). These last three statements represent the symptoms of "Nomophobia"(RodríguezGarcía et al., 2020), a term coined recently that designates the fear of remaining disconnected from the world. This is due to cell phone addiction and the abuse of social networks: anxiety and stress in the absence of a cell phone have become a real disease that affects anyone, regardless of gender or age (D'Elia et al., 2018). The most important factor of this research is given by the position taken while using the smartphone. Almost all of the students (90.1\%) adopt an incorrect posture: they put their cell phones down and tilt their heads to look at them, overloading the cervical vertebrae (Hansraj, 2014). Only $9.9 \%$ adopt good posture, with shoulders and head back and raising their arms to look at the screen, maintaining a neutral spine position (Figure 9). The prevalence of skeletal muscle disorders is higher in the neck/shoulders $(56.3 \%)$, and fingers I wrist $(27.2 \%)$, less prevalent in the back $(15.9 \%)$ and legs $(0.6 \%)$. Observing the relationship between the posture adopted during the use of the smartphone and the perceived pain area, we note that the students, who adopt a correct posture, placing the cell phone at the top, feel pain more both in the fingers/wrist and in the neck/shoulders (Figure 10). However, those who experience finger problems use their cell phone for less than 5 hours, while those who exceed 5 hours experience neck problems; instead, students who adopt an incorrect posture feel pain in the neck, followed by fingers, back and legs. A very high percentage (83.8\%), when they perceive pain or discomfort, put their mobile phone aside, while $16.2 \%$ continue to use it (Figure 11). To reduce pain, the majority $(70.7 \%)$ do nothing, $24.0 \%$ perform exercises, $5.1 \%$ take painkillers and $0.3 \%$ take physiotherapy sessions (Figure 12). On a psychic level, most of the samples (63.5\%) exhibit the classic symptoms of prolonged use of the smartphone, therefore feeling tired and concentration problems, sleep disturbances, $21.9 \%$ headache and nausea, the '11,7\% irritation and stress, $3.0 \%$ anxiety disorders (Figure 13). As many as $44.0 \%$ of students have reduced the time of use of the smartphone, this means that they have become aware of their mistakes, $30.2 \%$ have never thought about it, $14.7 \%$ have tried, but not he succeeded, while $11.1 \%$ did not care (Figure 14). The majority (47.3\%) do not feel dependent, 33.2\% feel dependent, and $19.5 \%$ do not know (Figure 15). Interestingly, the time of use of the current smartphone, of those who reduced it, is $71.5 \%$ of $4 / 5$ or more than 5 hours. Despite this, $47.3 \%$ said they did not feel dependent.

\section{CONCLUSION}

This research has established that "Text Neck" posture is associated with the occurrence of musculoskeletal neck disorders. Incorrect posture due to incorrect use of the smartphone, flexing the head to send messages and excessive time spent in this position, over time can lead to the presence of musculoskeletal pain in the neck region. The key to preventing any musculoskeletal problems is movement, but the majority said they did nothing to ease the pain. Only a very small part performs exercises. McKenzie exercises are perfect for Text Neck syndrome, since its treatment is more oriented towards education and adequate postural training (McKenzie \& Kubey, 2014). Although it is impossible to think of living without a cell phone, we can limit the damage caused by abuse. Some tips are correct your posture to reduce the inclination of the head and the pressure of the vertebrae on the discs by adopting a neutral position, reduce the time spent on the smartphone, perhaps replacing a call to the classic message, take breaks during the moments of use of the devices, with specific exercises for joint mobility. 


\section{REFERENCES}

Altavilla, G. (2014) Effects of the practice of muscle stretching, Sport Science, 7 (1), pp. 66-67. Cassese, F.P., Raiola, G. (2017) The importance of sport in disability management, Sport Science, 10, pp. 711.

Altavilla, G. (2016). Relationship between physical inactivity and effects on individual health status, Journal of Physical Education and Sport, 16 (Suppl. 2): 1069 - 1074.

Antonio-Manuel Rodríguez-García, Antonio-José Moreno-Guerrero, Jesús López Belmonte (2020) Nomophobia: An Individual's Growing Fear of Being without a Smartphone-A Systematic Literature Review. https://doi.org/10.3390/ijerph17020580

D'Elia, F., Mazzeo, F., \& Raiola, G. (2018). The core curriculum in the university training of the teacher of physical education in Italy. Journal of Human Sport and Exercise, 13(2proc), S413-S420. https://doi.org/10.14198/ihse.2018.13.Proc2.25

D'Elia, F. (2019). The training of physical education teacher in primary school. Journal of Human Sport and Exercise, 14(1proc), S100-S104. https://doi.org/10.14198/hhse.2019.14.Proc1.12

D'Isanto, T. (2016). Pedagogical value of the body and physical activity in childhood, Sport Science, 9 , 13-18.

D'Isanto, T. (2019) Physical and sport education between Italian academic system and European Research Council structure panel, Journal of Human Sport and Exercise, 14(Proc1), pp. S66 -S76. https://doi.org/10.14198/ihse.2019.14.proc1.08

D'Isanto, T., D'Elia, F., Raiola, G., Altavilla, G. (2019) Assessment of sport performance: Theoretical aspects and practical indications, Sport Mont, 17 (1), pp. 79-82.

Di Domenico, F., Fattore, S., \& D'santo, T. (2019). The movement: Complexity and reductionism, evidence in comparison. Journal of Human Sport and Exercise, 14(4proc), S602-S609. https://doi.org/10.14198/ihse.2019.14.proc4.18

Ferrara, F., Izzo, R., Ceciliani, A., Di Tore, A.P. Pilot study on the testing of Power Glove applied to volleyball (2019) Journal of Human Sport and Exercise, 14 (Proc2), pp. S233-S238. https://doi.org/10.14198/ihse.2019.14.proc2.11

Gaetano, R. (2012) Motor learning and didactics into physical education and sport documents in middle school-first cycle of education in Italy, Journal of Physical Education and Sport, 12 (2), pp. 157-163.

Hansraj, K.K. (2014). Assessment of stresses in the cervical spine caused by posture and position of the head. Surg Technol Int. 25:277-9.

Invernizzi, P.L., Signorini, G., Bosio, A., Raiola, G., Scurati, R. (2020) Validity and reliability of selfperception-based submaximal fitness tests in young adult females: An educational perspective Sustainability, 12 (6). https://doi.org/10.3390/su12062265

Invernizzi, P.L., Limonta, E., Bosio, A., Scurati, R., Veicsteinas, A., Esposito, F. (2014a) Effects of a 25$\mathrm{km}$ trial on psychological, physiological and stroke characteristics of short- And mid-distance swimmers Journal of Sports Medicine and Physical Fitness, 54 (1), pp. 53-62.

Invernizzi, P.L., Longo, S., Scurati, R., Maggioni, M.A., Michielon, G., Bosio, A. (2014b) Interpretation and perception of slow, moderate, and fast swimming paces in distance and sprint swimmers Perceptual and Motor Skills, 118 (3), pp. 833-849. https://doi.org/10.2466/27.29.pms.118k23w0

Invernizzi, P.L., Longo, S., Scurati, R. (2008) Analysis of heart rate and lactate concentrations during coordinative tasks: Pilot study in karate kata world champions Sport Sciences for Health, 3 (1-2), pp. 41-46. https://doi.org/10.1007/s11332-008-0053-7

Izzo, R., Raiola, G., D'isanto, T., Cejudo, A., Giovanelli, G.M. (2020a)Modelling an adequate profile for a more targeted work methodology, with dedicated technologies, for elite-level footballers: Comparison between sub 17 vs sub 19, highlights and shadows, Sport Science, 13 (1), pp. 36-42. 
Izzo, R., D'isanto, T., Raiola, G., Cejudo, A., Ponsano, N., Varde'i, C.H. (2020b) The role of fatigue in football matches, performance model analysis and evaluation during quarters using live global positioning system technology at 50hz, Sport Science, 13 (1), pp. 30-35.

Izzo, R., Giovannelli, M., Raiola, G. (2019a)Training load in elite goalkeepers with k-track for monitoring performance, Journal of Physical Education and Sport, 19, art. no. 280, pp. 1890-1896.

Izzo, R., Giovannelli, M., D'isanto, T. (2019b) The injury prevention program WTA functional primitive movement in professional football players: A case study Journal of Physical Education and Sport, 19 , art. no. 279 , pp. 1885-1889.

Izzo, R., Giovannelli, M., D'isanto, T. The injury prevention program WTA functional primitive movement in professional football players: A case study (2019c) Journal of Physical Education and Sport, 19, art. no. 279, pp. 1885-1889.

McKenzie, R., \& Kubey, C. (2014). 7 Steps To A Pain-Free Life: How to Rapidly Relieve Back, Neck Shoulder Pain Paperback.

Raiola, G. (2013) Body knowledge and motor skills, Knowledge Cultures, 1 (6), pp. 64-72.

Raiola, G. (2014) Motor control and learning skills according to cognitive and ecological dynamic approach in a vision on behaviorism, cognitive, Gestalt and phenomenology theories, Mediterranean Journal of Social Sciences, 5 (15), pp. 504-506. https://doi.org/10.5901/mjss.2014.v5n15p504

Raiola, G. (2015). Sport skills and mental health. Journal of Human Sport and Exercise, 10(1proc), S369S376. https://doi.org/10.14198//hse.2015.10.Proc1.27

Raiola, G. (2017) Motor learning and teaching method, Journal of Physical Education and Sport, 17, art. no. 236, pp. 2239-2243.

Raiola, G., Di Tore, P.A. (2017) Motor learning in sports science: Different theoretical frameworks for different teaching methods, Sport Science, 10, pp. 50-56.

Russo, G., Nigro, F., Raiola, G., Ceciliani, A. The role of the extra physical activity on memory storage and psychosocial features (2019a) Journal of Human Sport and Exercise, 14 (Proc4), pp. S948S956. https://doi.org/10.14198//hse.2019.14.proc4.57

Russo, G., Nigro, F., Raiola, G., Ceciliani, A. Self-esteem in physically active middle school students (2019b) Journal of Physical Education and Sport, 19, art. no. 295, pp. 1984-1988.

Tiziana, D., Antonetta, M., Gaetano, A. (2017). Health and physical activity, Sport Science, 10(1):100105.

Severino, N.C., Cassese, F.P., Ceciliani, A., D'elia, F., Di Tore, A.P. Psychophysical benefits of recreational five-a-side football (2019) Journal of Human Sport and Exercise, 14 (Proc2), pp. S206S214. https://doi.org/10.14198//hse.2019.14.proc2.07

Sgrò, F., Pignato, S., Lipoma, M. (2018) Assessing the impact of gender and sport practice on students 'performance required in team games Journal of Physical Education and Sport, 18, art. no. 71, pp. 497-502.

Sgrò, F., Quinto, A., Messana, L., Pignato, S., Lipoma, M. (2017a) Assessment of gross motor developmental level in italian primary school children Journal of Physical Education and Sport, 17 (3), art. no. 192, pp. 1954-1959.

Sgrò, F., Mango, P., Pignato, S., Schembri, R., Licari, D., Lipoma, M. (2017b) Assessing Standing Long Jump Developmental Levels Using an Inertial Measurement Unit Perceptual and Motor Skills, 124 (1), pp. 21-38. https://doi.org/10.1177/0031512516682649

Sgro', F., Quinto, A., Pignato, S., Lipoma, M. (2016) Comparison of product and process oriented model accuracy for assessing countermovement vertical jump motor proficiency in pre-adolescents Journal of Physical Education and Sport, 16 (3), art. no. 145, pp. 921-926.

Sgrò, F., Licari, D., Coppola, R., Lipoma, M. (2015)Assessment of balance abilities in elderly people by means of a clinical test and a low-cost force plate Kinesiology, 47 (1), pp. 33-43. 
Sgrò, F., Lo Bello, L., Lipoma, M. A networked embedded computing platform for physical activity assessment (2009) Proceedings - 2009 2nd Conference on Human System Interactions, HSI '09, art. no. 5090970, pp. 146-151. https://doi.org/10.1109/hsi.2009.5090970

Viscione, I., Invernizzi, P.L., Raiola, G. Physical education in secondary higher school (2019) Journal of Human Sport and Exercise, 14 (Proc4), pp. S706-S712. https://doi.org/10.14198/ihse.2019.14.proc4.31

Sannicandro, I. (2017) Effects of strength and core stability training versus strength and aerobic training in subjects aged over 65 [Article@Effetti dell'allenamento di forza e core stability versus allenamento di forza e aerobico a intensità controllata in soggetti over 65] Medicina dello Sport, 70 (4), pp. 410418.

Sannicandro, I., Cofano, G., Rosa, A.R. (2016) Heart rate response comparison of young soccer plyers in "cage" small-sided and 8vs8 games Journal of Physical Education and Sport, 16 (4), art. no. 180, pp. 1122-1127.

Sannicandro, I., Spedicato, M., Palaia, G., Cofano, G., Bisciotti, G.N., Eirale, C. (2015a) Strength ability, endurance and anthropometric parameters in youth football: Descriptive analysis and functional relationships [Article@Capacità di forza, endurance e parametri antropometrici nel calcio giovanile: Analisi descrittiva e rapporti funzionali] Medicina dello Sport, 68 (1), pp. 19-30.

Sannicandro, I., Piccinino, A., Cofano, G., Eirale, C., Biscotti, G.N. (2014) Effects of plyometric training on phases of jumping in young fencers [Article@Effetti dell'allenamento pliometrico sulle fasi del salto in giovani schermidori] Medicina dello Sport, 67 (1), pp. 27-45.

Sannicandro, I., Piccinno, A., Cofano, G., De Pascalis, S., Rosa, A.R. (2012a) Analysis of some variable performances of under 12 tennis players [Article@Analisi di alcune variabili prestative del giovane tennista under 12] Medicina dello Sport, 65 (4), pp. 473-484.

Sannicandro, I., Rosa, R.A., De Pascalis, S., Piccinno, A. (2012b) The determination of functional asymmetries in the lower limbs of young soccer players using the countermovement jump. The lower limbs asymmetry of young soccer players Science and Sports, 27 (6), pp. 375-377. https://doi.org/10.1016/i.scispo.2011.11.001

Sannicandro, I. Evaluation of muscle strength in young and top-level soccer players (2011a) [Article@La valutazione delia capacità di forza nel giovane calciatore e nel top level] Medicina dello Sport, 64 (1), pp. 9-20.

Sannicandro, I., Piccinno, A., Cataleta, R., Maffione, E., De Pascalis, S. (2010) The fencing lunee: Analysis of load distribution to the lower limbs and gender-related differences in young fencers in relation to accident prevention [Article@L'affondo nella scherma giovanile: Analisi del carico imposto ai due arti inferiori e differenze di genere per la prevenzione degli infortuni] Medicina dello Sport, 63 (3), pp. 353-364.

Sannicandro, I., Colella, D., Rosa, R.A., Manno, R. (2008) Modulation of motor load in old people: Effect of different exercise training protocols on power flexibility [Article@La modulazione del carico motorio in età avanzata: Effetti di differenti protocolli di training sui valori di forza, flessibilità ed endurance] Medicina dello Sport, 61 (4), pp. 443-454.

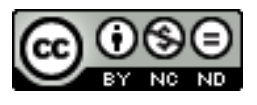

This work is licensed under a Attribution-NonCommercial-NoDerivatives 4.0 International (CC BY-NC-ND 4.0). 